\title{
Genetic Variability, Heritability and Genetic Advance for Yield and its Contributing Traits in Chickpea (Cicer arietinum L.)
}

\author{
Vartika Singh $^{1 *}$, S.C.Vimal ${ }^{1}$, Shiv Prakash Shrivastav ${ }^{1}$, \\ Virendra Maurya ${ }^{1}$ and Nidhi Singh ${ }^{2}$
}

${ }^{1}$ Department of Genetics and Plant Breeding, Narendra Deva University of Agriculture and Technology, Narendra Nagar (Kumarganj), Faizabad -224 229 (U.P.), India ${ }^{2}$ Department of Genetics and Plant Breeding, Tilakdhari Post Graduate College, Jaunpur-222002, (U.P.), India

*Corresponding author

\section{A B S T R A C T}

Keywords

chickpea (Cicer arietinum $L$.), Genetic variability, Heritability, Genetic advance, Seed yield, Quality parameter

\section{Article Info}

\section{Accepted:}

07 August 2020

Available Online: 10 September 2020
The experiment on forty genotypes along with three check varieties of chickpea (Cicer arietinum L.) were assessed to work out the genetic variability, heritability and genetic advance effects of their various attributes on seed yield. The high magnitude of genotypic and phenotypic coefficients of variation were observed for seed yield per plant, 100- seed weight, seeds per pod, primary branches per plant and pods per plant, indicating thereby, substantial scope for improvement in this character after hybridization and subsequent selection and the high estimate of heritability with high genetic advance in per cent of mean were observed for 100seed weight, seed yield per plant and seeds per pod. The highest seed yield per plant was produced by KWR 108 (18.84 g ), while the lowest seed yield per plant were given by BGD 1081 and Phule G $0405(6.60 \mathrm{~g})$. High heritability and genetic advance indicate that the additive nature of gene action and reliability of those characters for selection and emerged as ideal traits for improvement through selection.

\section{Introduction}

Chickpea (Cicer arietinum L.) crop is selfpollinated and diploid $(2 \mathrm{n}=2 \mathrm{x}=16)$ species. It is belongs to genus Cicer, tribe Cicereae, family Fabaceae, and subfamily Papilionaceae. It originated in south-eastern Turkey. The Cicer is of Latin origin, derived from the greek word 'kikus' meaning force or strength. Among pulse, chickpea occupies a premier position in respect of area and production in the world. It is grown in an area $13.20 \mathrm{~m}$ ha and the production is around $11.60 \mathrm{~m}$ tonnes with an average productivity of $880 \mathrm{~kg}$ per ha. India is also greater consumer as well as importer of chickpea in the world. In India, chickpea is grown about $9.93 \mathrm{~m}$ ha area and producing $9.53 \mathrm{~m}$ tonnes grain with productivity of $960 \mathrm{~kg}$ per ha. In Utter Pradesh, it is cultivated on area of 577 
thousand ha with grain yield production is 475 thousand tonnes and productivity of wheat crops is $824 \mathrm{~kg}$ per ha respectively 2013-14 (Anonymous, 2015). It is cultivated throughout the country excepting high altitude and costal region. However, the major chickpea producing state are Madhya Pradesh, Rajasthan, Maharashtra, Karnataka and Andhra Pradesh, which contribute more than 90 per cent of the national production.

\section{Materials and Methods}

The study was designed to work out the status of genetic variability, heritability and genetic advance effects of these different traits on seed yield per plant among forty chickpea genotypes at field experiment under present investigation was conducted during Rabi 2014-15 at the Student's Instructional Farm and lab experiments were conducted in Seed Testing Laboratory, Seed Technology Section, N. D. University of Agriculture and Technology, Narendra Nagar (Kumarganj), Faizabad (U.P.) India. The experimental materials of studies comprised of forty chickpea varieties/ lines/ genotypes excluding three check varieties viz., GCP 105, KWR108 and DCP92-3 these varieties were procured from genetic stock available in pulse section, Department of genetics and Plant Breeding, N. D. University of Agriculture and Technology, Narendra Nagar (Kumarganj), Faizabad (U.P.) India. The experiment was laid out in Randomized Block Design. The soil type of experimental site was sandy loam, low in organic carbon, nitrogen, phosphorus and rich in potash. The observation were recorded on twelve different seed yield traits viz., Days to $50 \%$ flowering, Days to maturity, Plant height $(\mathrm{cm})$, Number of primary branches per plant, Number of secondary branches per plant, Number of pods per plant, Number of seeds per pod, 100seed weight (g), Germination (\%), Seedling length $(\mathrm{cm})$, Vigour index and Seed yield per plant $(\mathrm{g})$. Seed germination percentage was investigated under lab condition germination was estimated on the basis of 100 randomly selected kept for germination in germination paper at room temperature in germinator. The samples were kept in seed germinator maintained at $20^{\circ} \mathrm{c} \pm 1$. Ten seedlings were randomly taken from each replication. On $8^{\text {th }}$ day seedlings were measured on meter scale, the unite length was in $\mathrm{cm}$. The vigour index was conducted as per the method prescribed by Abdul-Bali and Anderson (1973) and expressed in whole number. The seed were kept for germinate fallowing ISTA method. The seedling was measured for seedling length to obtain seedling length.

\section{Results and Discussion}

Analysis of variance revealed highly significant difference among the genotypes for all the characters except primary branches per plant and seeds per pod, which validated further statistical and genetical analysis (Table 1). The assessment of existing variability in the germplasm collections was done by computing range and least significant differences. The heritability in broad sense (Hanson et al., 1956) and genetic advance in per cent of mean (Johnson et al., 1955) were calculated for understanding the transmissibility of characters.

In order to evaluate the germplasm collections, the mean performance of 40 chickpea genotypes and 3 checks for 12 characters is presented in Table 2. Very wide range of variation in mean performance of genotypes was observed for all the characters under study. The entry, GL 10023 produced highest seed yield per plant (15.40 g) and also showed high mean performance for Pods/plant and Plant height. The ten genotypes possessing higher seed yield per plant along with the highest yielder GL 10023, RKG 12-163, RKG 964, BDNG 804, 
BG 3043, IPC 2010-14, RKG 12-206, BG 3003, BG 3021 and BG 3032. These ten genotypes also showed high mean performance for some other characters besides having higher yield. GL 10023 (15.40 g) to constitute top significant group for seed yield per plant superior two genotypes. Among them RKG 12-163 which ranked second $(13.20 \mathrm{~g})$ was present in highest mean performance group for Seeds/pod, Pods/plant, Days to maturity. In addition to the genotypes mentioned above, some other genotypes showing very high mean performance for other characters can be used as donors for improving those characters in a component breeding approach even if they have medium or low seed yield. In this context, the most desirable genotypes were RKG 12-296, BG 3033, IPC 2010-17, DKG 964, GL 1006, GJC 1114, BG 3043 and BG 3032 for early flowering; GL 1006, RKG 12-296, BG 3032, BG 3033, GNG 1947, CSJ 84, IPC 2010-17, RKG $12-163$ and BG 3003 for early maturity; BGD 1081, BGD 1080, PG 0127, GL1023, Phule G 0405 and GNC 2216 for dwarf plant height; JC 36, PG 0127, RKG 12-163, GL 1000, BG 3031, BG 3033,BG 3024, AKG
1108, BGD 1081 and GL 10023 primary branches plant; GJC 1114, BG 3043, BG 3027, JG 36, AKG 1108, RKG 12-163, GL 10023, Phule G 0408, Phule G 0405, BONG 804 and RKG 12-296 for secondary branches per plant; GL 10023, BG 3043, BDNG 804, BG 3021, BG 3024, RKG 12-296, GL 1006, GNG 2216, GNG 1926, GNG 1947, IPC 2010-17, H 10-12, BGD 1081, RKG 12-163, Phule G 0408, Phule G 0405 and GNG 1854 for pods per plant; GNG 2207, DC 2012-5, JG 36, IPC 2010-14, CSJ 513, BAOG 15, BGD 1081,RKG 12-163, Phule G 0408, BG 256, BG 3024 and BG 3032 for seeds per pod; BG 3033, B 3024, BG 256, BG 3044, PG 0127, Phule G 0408, GNG 2216 and IPC 2010-14 for 100-seed weight; BG 3033, GNG 1926, BGD 804, PG 1854, BG 3021, BG 256, RKG 12-296, GNG 1107, CSJ 821 and AKG 1108 for germination \%; BDG 1081, AKG 1108, BADG 15, PG 0127, Phule G 0408, DKG 964, GJG 1114, RKG 12-296, BG 2088 and GNG 1926 for seedling length; GNG 1926, AKG 1108, BADG 15, PG 0127, Phule G 0408, DKG 964, GJG 1114, RKG 12-296, BG 2088, BG 22021, BG 2033 and GNG 1854 for vigour index.

Table.1 Analysis of variance for different characters of chickpea genotypes

\begin{tabular}{|l|c|c|c|}
\hline \multirow{2}{*}{ Characters } & \multicolumn{3}{|c|}{ Source of variation } \\
\hline Degree of freedom & Replications & Treatments & Error \\
\hline Days to 50\% flowering & $\mathbf{2}$ & $\mathbf{4 2}$ & $\mathbf{8 4}$ \\
\hline Days to maturity & 0.21 & $31.73^{* *}$ & 2.95 \\
\hline Plant height (cm) & 2.58 & $30.98^{* *}$ & 2.84 \\
\hline Primary branches/plant & 3.56 & $107.95^{* *}$ & 13.25 \\
\hline Secondary branches/plant & 0.01 & $0.36^{*}$ & 0.03 \\
\hline Pods/plant & 0.03 & $2.54^{* *}$ & 0.32 \\
\hline Seeds/pod & 10.72 & $137.15^{* *}$ & 18.35 \\
\hline 100-seed weight $\mathbf{( g )}$ & 0.008 & $0.28^{*}$ & 0.02 \\
\hline Germination $(\mathbf{\%})$ & 0.49 & $65.75^{* *}$ & 3.63 \\
\hline Seedling length $(\mathbf{c m})$ & 0.05 & $15.71^{* *}$ & 2.79 \\
\hline Vigour index & 0.65 & $10.56^{* *}$ & 1.53 \\
\hline Seed yield/plant $\mathbf{( g )}$ & 979.65 & $110410.17^{* *}$ & 1494.70 \\
\hline
\end{tabular}

*, ** Significant at $5 \%$ and $1 \%$ probability level, respectively 
Table.2 Adjusted means of forty genotypes and three checks, range and least significant difference for different characters in chickpea

\begin{tabular}{|c|c|c|c|c|c|c|c|c|c|c|c|c|c|}
\hline S.N & Genotypes & $\begin{array}{c}\text { Days to } \\
50 \% \\
\text { flowering }\end{array}$ & $\begin{array}{l}\text { Days to } \\
\text { maturity }\end{array}$ & $\begin{array}{l}\text { Plant } \\
\text { height } \\
\text { (cm) }\end{array}$ & $\begin{array}{c}\text { Primary } \\
\text { branches/ } \\
\text { plant }\end{array}$ & $\begin{array}{c}\text { Secondary } \\
\text { branches/ } \\
\text { plant }\end{array}$ & $\begin{array}{l}\text { Pods/ } \\
\text { plant }\end{array}$ & $\begin{array}{l}\text { Seeds/p } \\
\quad \text { od }\end{array}$ & $\begin{array}{l}\text { 100-seed } \\
\text { weight } \\
\text { (g) }\end{array}$ & $\begin{array}{c}\text { Germination } \\
(\%)\end{array}$ & $\begin{array}{l}\text { Seedling } \\
\text { length } \\
\text { (cm) }\end{array}$ & $\begin{array}{l}\text { Vigour } \\
\text { index }\end{array}$ & $\begin{array}{c}\text { Seed } \\
\text { yield } \\
\text { /plant (g) }\end{array}$ \\
\hline 1 & CSJ 513 & 99.00 & 143.00 & 53.40 & 2.20 & 7.40 & 44.60 & 1.80 & 16.00 & 89.00 & 23.80 & 2118.20 & 10.20 \\
\hline 2 & AKG 1108 & 101.00 & 148.00 & 51.80 & 2.60 & 8.00 & 49.40 & 1.40 & 22.50 & 95.00 & 24.65 & 2341.75 & 10.00 \\
\hline 3 & GNG 2207 & 98.00 & 142.00 & 49.60 & 2.20 & 5.80 & 44.40 & 2.00 & 15.50 & 93.50 & 18.85 & 1762.47 & 9.00 \\
\hline 4 & CSJ 821 & 97.00 & 140.00 & 45.00 & 2.20 & 7.00 & 42.40 & 1.60 & 15.00 & 95.00 & 17.90 & 1700.50 & 7.20 \\
\hline 5 & DC 2012-5 & 98.00 & 145.00 & 51.20 & 2.00 & 5.60 & 38.80 & 2.00 & 15.00 & 94.00 & 21.05 & 1978.70 & 9.40 \\
\hline 6 & GNG 1107 & 100.00 & 145.00 & 41.00 & 2.00 & 7.20 & 46.60 & 1.40 & 16.50 & 95.00 & 22.55 & 2142.25 & 9.60 \\
\hline 7 & BADG 15 & 98.00 & 142.00 & 52.20 & 2.40 & 6.80 & 44.20 & 1.80 & 24.50 & 93.00 & 24.00 & 2232.00 & 7.60 \\
\hline 8 & PG 0127 & 98.00 & 145.00 & 56.20 & 2.80 & 7.40 & 43.00 & 1.40 & 27.50 & 93.00 & 24.10 & 2241.30 & 10.40 \\
\hline 9 & BGD 1080 & 100.00 & 147.00 & 57.20 & 2.40 & 6.80 & 45.80 & 1.40 & 19.50 & 96.00 & 22.60 & 2169.60 & 10.00 \\
\hline 10 & IPC 2010-17 & 93.00 & 140.00 & 52.20 & 1.40 & 6.80 & 53.00 & 1.60 & 17.00 & 90.00 & 21.15 & 1903.50 & 9.60 \\
\hline 11 & H 10-12 & 99.00 & 146.00 & 49.40 & 2.40 & 6.00 & 50.40 & 1.60 & 16.50 & 94.00 & 23.20 & 2180.80 & 10.20 \\
\hline 12 & JG 36 & 97.00 & 143.00 & 52.80 & 3.00 & 8.80 & 46.80 & 2.00 & 15.00 & 94.50 & 23.25 & 2197.12 & 8.60 \\
\hline 13 & BGD 1081 & 98.00 & 145.00 & 59.40 & 2.60 & 7.80 & 53.40 & 1.80 & 22.00 & 93.00 & 24.70 & 2297.10 & 6.60 \\
\hline 14 & RKG 12-163 & 96.00 & 141.00 & 51.20 & 2.80 & 8.00 & 52.40 & 1.80 & 25.00 & 94.00 & 23.15 & 2176.10 & 13.20 \\
\hline 15 & GL 10023 & 97.00 & 145.00 & 56.00 & 2.60 & 8.40 & 66.00 & 1.40 & 25.00 & 94.00 & 23.25 & 2185.50 & 15.40 \\
\hline 16 & Phule G 0408 & 98.00 & 148.00 & 53.80 & 2.40 & 8.20 & 54.00 & 1.80 & 26.00 & 92.00 & 24.00 & 2208.00 & 6.60 \\
\hline 17 & BG 3044 & 96.00 & 145.00 & 54.00 & 2.20 & 7.20 & 40.00 & 1.20 & 28.50 & 94.00 & 21.40 & 2011.60 & 10.40 \\
\hline 18 & Phule G 0405 & 101.00 & 148.00 & 56.00 & 2.00 & 8.00 & 51.00 & 1.20 & 21.00 & 86.00 & 18.85 & 1621.10 & 11.60 \\
\hline 19 & GL 1006 & 95.00 & 139.00 & 62.80 & 2.80 & 7.80 & 50.60 & 1.40 & 24.00 & 92.00 & 22.50 & 2070.00 & 11.00 \\
\hline 20 & GNG 2216 & 100.00 & 145.00 & 56.80 & 2.60 & 7.20 & 55.60 & 1.60 & 26.00 & 92.00 & 22.65 & 2083.80 & 8.20 \\
\hline 21 & NBe G 452 & 99.00 & 149.00 & 54.00 & 2.20 & 7.40 & 42.00 & 1.60 & 22.50 & 91.00 & 23.05 & 2097.55 & 10.60 \\
\hline 22 & DKG 964 & 94.00 & 143.00 & 55.80 & 2.40 & 7.60 & 56.40 & 1.00 & 16.00 & 94.00 & 24.10 & 2265.40 & 16.40 \\
\hline 23 & GJG 1114 & 95.00 & 142.00 & 52.60 & 2.40 & 9.00 & 41.80 & 1.60 & 21.50 & 94.00 & 24.25 & 2279.50 & 6.80 \\
\hline 24 & BDNG 804 & 98.00 & 144.00 & 46.40 & 2.40 & 8.00 & 61.20 & 1.00 & 20.00 & 96.00 & 18.30 & 1756.80 & 12.80 \\
\hline 25 & BG 3043 & 95.00 & 142.00 & 46.80 & 2.40 & 8.80 & 64.20 & 1.60 & 22.00 & 91.50 & 22.75 & 2081.62 & 15.40 \\
\hline 26 & IPC 2010-14 & 100.00 & 148.00 & 47.60 & 1.80 & 6.20 & 47.80 & 2.00 & 26.00 & 90.00 & 22.60 & 2034.00 & 12.00 \\
\hline 27 & RKG 12-296 & 90.00 & 140.00 & 42.60 & 1.80 & 8.20 & 58.60 & 1.40 & 15.50 & 95.00 & 24.15 & 2294.25 & 12.00 \\
\hline 28 & BG 256 & 104.00 & 149.00 & 45.60 & 2.40 & 7.20 & 43.80 & 1.80 & 27.00 & 95.00 & 22.15 & 2104.25 & 9.00 \\
\hline 29 & BG 2088 & 99.0 & 145.00 & 44.80 & 1.80 & 6.40 & 48.20 & 1.40 & 15.50 & 94.00 & 24.40 & 2293.60 & 8.80 \\
\hline 30 & BG 3003 & 96.00 & 141.00 & 52.20 & 2.20 & 7.00 & 45.60 & 1.60 & 25.50 & 94.50 & 18.25 & 1724.62 & 13.80 \\
\hline 31 & BG 3021 & 98.00 & 149.00 & 52.00 & 2.40 & 7.40 & 59.70 & 1.40 & 23.00 & 95.00 & 23.20 & 2204.00 & 16.20 \\
\hline 32 & BG 3024 & 104.00 & 148.00 & 51.40 & 2.60 & 8.60 & 54.00 & 1.80 & 28.00 & 94.00 & 22.90 & 2152.60 & 9.20 \\
\hline
\end{tabular}




\begin{tabular}{|c|c|c|c|c|c|c|c|c|c|c|c|c|c|}
\hline 33 & BG 3027 & 101.00 & 147.00 & 52.20 & 2.00 & 7.80 & 47.60 & 1.20 & 20.50 & 89.00 & 22.75 & 2024.75 & 10.80 \\
\hline 34 & BG 3031 & 98.00 & 146.00 & 49.00 & 2.60 & 7.20 & 41.00 & 1.40 & 27.50 & 91.00 & 21.60 & 1965.50 & 9.20 \\
\hline 35 & BG 3032 & 95.00 & 140.00 & 42.20 & 1.80 & 7.00 & 47.00 & 1.80 & 22.00 & 93.00 & 23.35 & 2171.55 & 13.60 \\
\hline 36 & BG 3033 & 90.00 & 140.00 & 45.40 & 2.80 & 7.20 & 38.80 & 1.00 & 29.00 & 96.50 & 23.10 & 2229.15 & 11.80 \\
\hline 37 & GNG 2065 & 98.00 & 147.00 & 44.00 & 2.20 & 7.00 & 43.00 & 1.00 & 19.50 & 90.00 & 19.15 & 1723.50 & 9.20 \\
\hline 38 & GNG 1854 & 100.00 & 149.00 & 41.00 & 2.20 & 7.60 & 53.60 & 1.20 & 24.00 & 95.00 & 23.70 & 2251.50 & 7.20 \\
\hline 39 & GNG 1926 & 99.00 & 145.00 & 33.20 & 2.00 & 6.40 & 51.60 & 1.00 & 13.50 & 96.00 & 24.45 & 2347.20 & 8.20 \\
\hline \multirow[t]{4}{*}{40} & GNG 1947 & 99.00 & 140.00 & 41.80 & 2.00 & 6.40 & 45.60 & 1.60 & 13.50 & 94.00 & 23.05 & 2166.70 & 8.00 \\
\hline & GCP 105 (c) & 95.00 & 147.00 & 42.00 & 2.20 & 5.60 & 44.40 & 1.40 & 17.30 & 93.00 & 21.25 & 1976.25 & 10.75 \\
\hline & KWR 108 (c) & 89.00 & 138.00 & 44.00 & 3.00 & 7.00 & 49.60 & 2.00 & 19.00 & 96.00 & 23.75 & 2280.00 & 18.84 \\
\hline & DCP 92-3 (c) & 93.00 & 141.00 & 44.20 & 2.20 & 4.80 & 40.00 & 2.00 & 16.50 & 90.00 & 20.46 & 1841.40 & 11.55 \\
\hline
\end{tabular}

Table.3 Estimate of range, grand mean, phenotypic (PCV) and genotypic (GCV) coefficient of variation, heritability in broad sense $\left[\mathrm{h}^{2}(\mathrm{bs}) \%\right]$ and genetic advance in per cent of mean ( $\left.\overline{\mathrm{Ga}} \%\right)$ for different characters in chickpea genotypes

\begin{tabular}{|c|c|c|c|c|c|c|}
\hline \multirow[t]{2}{*}{ Characters } & \multirow{2}{*}{$\begin{array}{c}\text { Range } \\
\text { (Lowest- Highest) }\end{array}$} & \multirow[b]{2}{*}{$\frac{\text { Grand }}{\operatorname{Mean}\left(\bar{X}_{i}\right)}$} & \multicolumn{2}{|c|}{ Coefficient of variation } & \multirow{2}{*}{$\begin{array}{c}\text { Heritability in } \\
\text { broad sense }(\%) \\
{\left[\mathbf{h}_{(\mathbf{b s})}^{2} \%\right]}\end{array}$} & \multirow{2}{*}{$\begin{array}{c}\text { Genetic advance in } \\
\text { per cent of mean } \\
(\overline{\mathrm{Ga}} \%)\end{array}$} \\
\hline & & & $\operatorname{PCV}(\%)$ & GCV (\%) & & \\
\hline Days to $50 \%$ flowering & $89.00-104.00$ & 97.40 & 3.63 & 3.18 & 76.50 & 5.73 \\
\hline Days to maturity & $138.00-149.00$ & 144.23 & 2.42 & 2.12 & 76.73 & 3.83 \\
\hline Plant height $(\mathrm{cm})$ & $33.20-62.80$ & 49.60 & 13.49 & 11.33 & 70.44 & 19.58 \\
\hline Primary branches/plant & $1.40-3.00$ & 2.31 & 16.20 & 14.39 & 78.88 & 26.33 \\
\hline Secondary branches/plant & $4.80-9.00$ & 7.26 & 14.18 & 11.88 & 70.13 & 20.49 \\
\hline Pods/plant & $38.80-66.00$ & 48.79 & 15.60 & 12.90 & 68.33 & 21.96 \\
\hline Seeds/pod & $1.00-2.00$ & 1.53 & 21.74 & 19.15 & 77.51 & 34.72 \\
\hline 100-seed weight (g) & $13.50-29.00$ & 21.00 & 23.49 & 21.67 & 85.10 & 41.18 \\
\hline Germination (\%) & $86.00-96.50$ & 93.17 & 2.86 & 2.23 & 60.67 & 3.57 \\
\hline Seedling length $(\mathrm{cm})$ & $17.90-24.70$ & 22.43 & 9.50 & 7.73 & 66.27 & 12.97 \\
\hline Vigour index & $1621.10-2347.20$ & 2090.40 & 9.30 & 9.11 & 96.05 & 18.40 \\
\hline Seed yield/plant & $6.60-18.84$ & 10.63 & 28.46 & 25.69 & 81.51 & 47.79 \\
\hline
\end{tabular}


The success of selection in improving plant characters depends mainly on presence of substantial genetic variability and nature of heritability and gene action. The genetic variability is the raw material of plant breeding programme on which selection acts to evolve superior genotypes. The phenotypic and genotypic coefficients of variation can be used for assessing and comparing the nature and magnitude of variability existing for different characters in the breeding materials. Heritability in broad sense quantifies the proportion of heritable genetic variance to total phenotypic variance, while heritability in narrow sense represents the ratio of fixable additive genetic variance to total phenotypic variance. Estimates of heritability help in estimating expected progress through selection. The genetic advance in per cent of mean provides indication of expected selection response by taking into account the existing genetic variability and heritability of the character.

The estimates of direct selection parameters, coefficients of variation, heritability and genetic advance in per cent of mean were computed for 12 characters of 40 genotypes (Table 3). The high estimates $(>15 \%)$ of phenotypic (PCV) and genotypic (GCV) coefficients of variation were recorded in case of seed yield per plant (PCV $=28.63 \%$, $\mathrm{GCV}=25.69 \%$ ) followed by 100 -seed weight, seeds per pod and while primary branches per plant and pods per plant showed high PCV along with moderate GCV. Moderates estimates $(<15 \%->10 \%)$ of PCV and GCV were noted for secondary branches per plant $(\mathrm{PCV}=14.18 \%, \quad \mathrm{GCV}=11.885)$ and plant height whereas, the low estimates $(<10 \%)$ of phenotypic and genotypic coefficients variation were observed for seedling length (PCV=9.50\%, GCV=7.73\%), vigour index, days to $50 \%$ flowering, germination and days to maturity. (Chavan et al., 1995, Jahagirdar et al., 1995, Mishra et al., 1998, Tripathi,
1998, Kumar et al., 1999, Suryawanshi et al., 1999, Wahid and Ahmad, 1999, Jeena and Arora, 2000, Kumar et al., 2001, Ali et al., 2002, Khan et al., 2006, Lokere et al., 2007, Ojha et al., 2010).

The magnitude of heritability in broad sense varied between $60.67 \%$ in case of germination to $96.05 \%$ for vigour index. The high estimates of broad sense heritability (> 75\%) were noted for vigour index $(96.05 \%), 100-$ seed weight, seed yield per plant primary branches per plant, seeds per pod and days to maturity and days to $50 \%$ flowering. Moderates estimates of heritability (> 65 to < $75 \%$ ) were observed for plant height (70.44\%), secondary branches per plant (70.13\%), pods per plant and seedling length while germination showed low estimate of heritability. The genetic advance in per cent of mean ranged from $3.57 \%$ for germination to $47.79 \%$ for seed yield per plant.

The very high estimates of genetic advance $(>30 \%)$ were registered for seed yield per plant $(47.79 \%)$ followed by 100 - seed weight and seeds per pods, while the high estimates of genetic advance $(<20 \%)$ were recorded for primary branches per plant, pods per plant and secondary branches per plant. The moderate estimates of genetic advance $(<20 \%$ to $>10 \%$ ) were observed for plant height, vigour index and seedling length. The low estimates of genetic advance $(<10 \%)$ were identified for days to $50 \%$ flowering $(5.73 \%)$, days to maturity and seed germination. (Mathuraj et al., 2001, Biradar et al., 2007, Vaghela et al., 2009, Sreelakshmi et al., 2010, Dar et al., 2012, Hasan et al., 2013, Kumar et al., 2015).

Considering the overall result it is apparent that certain information obtained here will help in future for improving existing chickpea varieties. 


\section{References}

Ali S, Maher AB and Anwand HAM. 2002. Exploitation of genetic variability for grain yield improvement in chickpea. International J. Agric. and Bio., 4(10): 148-149.

Anonymous. 2015. All Indian Coordinated Research Project on Chickpea.

Biradar KS, Sailmath, PM and Ravikumar RL. 2007. Genetic variability for seedling vigour, yield and yield components in local germplasm collections of greengram (Vigna radiate (L.) Wilczek). Karnataka J. of Agri. Sci., 20(3):608-609.

Chavan VW, Patil HS and Rasal RN. 1995. Genetic variability, correlation studied and their implications in selection of high yielding genotypes of chickpea. Madras Agric., J. 81(9):463-465.

Dar SA, Ishfaq A, Khan MH, Pir FA, Gowhar A and Manzar A. 2012. Studies on genetic variability and interrelationship for yield and yield component characters in chickpea (Cicer arietinun L). Trends in biosciences, 5(2):119-121.

Hanson GH, Robinson HF and Comstock RE. 1956. Biometrical studies of yield in segregating populations of Korean Lespedeza. Agron. J., 48:267-282.

Hasan MT and Deb AC. 2013. Genetic variability and correlation study in chickpea (Cicer arietinum L.). International Journal of Sustainable Agriculture Technology, 9(1):8-11.

Jahagirdar JE, Patil RA and Khare PR 1995. Genetic variability and its relevance in chickpea improvement. Indian J. Pulses Res., 7(2):179-180.

Jeena AS and Arora PP. 2000. Role of variability for improvement in chickpea. Legume Res., 24(2): 135136.

Johnson HW, Robinson HF and Comstock
RE. 1955. Estimation of genetic and environmental variability in soybean. Agron., J. 47: 314-318.

Khan H, Ahmad SQ, Ahmad F, Khan MS and Nayyar I. 2006. Genetic variability and correlation among quantitative traits in gram. Sarhad J. Agri., 22(1): 55-59.

Kumar S, Arora PP and Jeena AS. 2001. Genetic variability studied for quantitative traits in chickpea. Agric. Sci. Digest, 2(4): 263-264.

Kumar V, Kar CS, Sharma PC and Kumar V. 1999. Variability, correlation and path coefficient analysis in chickpea (Cicer arietinum L.). Environment and Ecology, 17(4):936-939.

Kumar VVG, Abrahum MB, Anitha Y, Lakshmi NJ and Maheswari M. 2015. Variability, heritability and genetic advance for quantitative traits in blackgram (Vigna mungo (L.) Hepper). Int J Curr Sci., 17(2):37-42.

Lokere YA, Patil JV and Chavan UD. 2007. Genetic analysis of yield and quality traits in kabuli chickpea. J. Food Legumes, 20(2):147-149.

Mishra R, Rao SK and Koutu GK 1998. Genetic variability, correlation studies and their implication in selection of high yielding genotypes of chickpea. Indian J. Agric. Res., 22(1):51-57.

Muthuraj R, Kant K and Dadlani M. 2001. Heritability of seed quality characters in soybean (Glycine max L. Merrill). Seed Res., 29(2):158-160.

Ojha VS, Natha S and Singh R. 2010. Genetic variability in chickpea (Cicer arietinum L.). Progressive Research, 5(2):275-276.

Sreelakshmi C, Shivani D and Kumar CVS. 2010. Genetic divergence, variability and character association studies in bengal gram (Cicer arietinum L.). Electronic Journal of Plant Breeding, 1(5): 1339-1343. 
Suryawanshi YB, Purkar JK and Patil RB 1999. Seed quality in relation to seed coat colour and seed size in chickpea. Univ. Of Agri. Sci. 28(7/8):104-105.

Tripathi AK. 1998. Variability analysis in chickpea. Zonal Agril. Res., 11(2):291-292.

Vaghela MD, Poshiya VK, Savaliya JJ, Kavani RH and Davada BK. 2009. Genetic variability studies in kabuli chickpea (Cicer arietinum L.). Legume Research 32(3)191-194.

Wahid MA and Ahmad R. 1999. Genetic variability, correlation studies and their implication in selection on high yielding genotypes in chickpea (Cicer arietinum L.). Sarhad. J. Agril., 15(1):25-28.

\section{How to cite this article:}

Vartika Singh, S.C.Vimal, Shiv Prakash Shrivastav, Virendra Maurya and Nidhi Singh. 2020. Genetic Variability, Heritability and Genetic Advance for Yield and its Contributing Traits in Chickpea (Cicer arietinum L.). Int.J.Curr.Microbiol.App.Sci. 9(09): 445-452.

doi: https://doi.org/10.20546/ijcmas.2020.909.056 